\title{
Website Characterization and Evaluation of the Five Star Hotels in Saudi Arabia Using Advanced Content Analysis and eMICA Framework
}

\author{
Dr. Shafeeq M. Assiri ${ }^{1}$, Shajahan Shamsudeen ${ }^{2 *}$ \\ ${ }^{1}$ Vice Dean for Development and Quality, Marketing \& E-Commerce Dept. Acting Head, College of Business Administration, Jazan University, Al \\ Maarefah Rd, Jizan Saudi Arabia \\ ${ }^{2}$ Professor, Ministry of Education, Jazan University, CBA Kingdom of Saudi Arabia
}

\begin{abstract}
About the authors
Dr. Shafeeq M. Assiri is a Hospitality Management specialist and excellent academic administrator who took his PhD in Hospitality management from Texas Tech University USA and Masters in Hospitality Management from Florida International University USA. He has been honored by Golden key International Honor Society USA for his academic excellence in 2015 and Regional Tourism Festival Board for his societal contribution in 2011. $\mathrm{He}$ is presently working as Vice Dean for Development and Quality, Marketing \& E-Commerce Dept. Acting Head, College of Business Administration of Jazan University KSA Contact : linkedin.com/in/dr-shafeeq-m-assiri-3542541a

Prof. Shajahan Shamsudeen is a Management specialist from Wharton and HBS whose qualifications include MBA in Marketing and PhD in Marketing Management with Fellowship and Lectureship from University Grants Commission (UGC), New Delhi \& International Finance Corporation (IFC) Washington USA; having 19 years of Post-Doctoral Business Teaching experience including 6 Years in CBA, Jazan University, Ministry of Education KSA as Full Time Professor \&Trainer for Quality Improvement Program for Faculty Development (QIPFD) and Dept. Co-ordinator for Curriculum Review Board and New Curriculum Committee. He authored 16 text books in Management and published 290 research/conference papers, Chaired 35 international seminars and received 25 awards globally. He can be contacted drshamsudeen@jcba.edu.sa
\end{abstract}

DOI: $10.36348 /$ sjbms.2019.v04i09.001

| Received: 10.05.2019 | Accepted: 21.05.2019| Published: 16.09.2019

*Corresponding author: Shajahan Shamsudeen

\section{Abstract}

This study analyzed the features offered by the websites of the premium and luxury 42 five star hotels in Saudi Arabia on six regions namely Riyadh, Jeddah, Makkah, Madinah, Abha and Jazan Regions of Saudi Arabia during 2018-19. The study evaluated the hotel websites under study based on eMICA stages of promotion, provision, and processing and also grouped in seven dimensions determined by the advanced content analysis. The study also provided insight into hotel websites characterization framework for consumer's information needs on nine parameters as well. It was established from the findings of the study that Saudi Arabian five star hotel websites were yet to utilize the potentiality of their website as a tool for marketing hotel product and services. The aggregate average value of 9 functionality dimensions in this regard was only 36.2 per cent. This is further highlighted with their poor score in reservation functions (2.4\%), website functionality $(18.8 \%)$ and product information $(35.9 \%)$. The study found that the development of the most of the hotel websites we studied fell into the second stage of eMICA model, with the exception of Jazan and Abha regions hotels websites, which were in the first stage of development. The study findings hope to aid web marketing of five star hotels for providing the new age customer digital experience for the e-visitors of Saudi Arabian five star premium and luxury hotels.

Keywords:Hotel website evaluation, Content analysis, eMICA, Website characterization and Website quality. Copyright @ 2019: This is an open-access article distributed under the terms of the Creative Commons Attribution license which permits unrestricted use, distribution, and reproduction in any medium for non-commercial use (NonCommercial, or CC-BY-NC) provided the original author and source are credited.

\section{INTRODUCTION}

The rapid development of Information and Communication Technologies (ICTs) over the last decades has changed the tourism and hospitality industries in Saudi Arabia. ICTs have become powerful tools to help in the dissemination of tourist activities within the Kingdom and enhanced the competitiveness of Saudi Hotel industry from segments such as transport to accommodation, as well as catering and entertainment. According to Arabian Travel Market 
(ATM) travel research report in 2018, reforms and investment were driven hotel, travel and tourism sectors in Saudi Arabia and would continue for the next five years. Further, recent reforms in Saudi Arabia will drive growth in the hospitality market of $13.5 \%$ compound annual growth rate (CAGR), higher than the established markets of the UAE $(10.1 \%)$ and Oman $(11.8 \%)$. This is good news for the hospitality industry in KSA.

An online presence is necessary for the survival and competitiveness of hoteliers globally as the luxury hotel chain dominates the scenario in KSA. Among other advantages, an online presence allows the disclosure, booking and sale of accommodations through direct channels, according to customers' preferences. In this context, it is widely accepted that the Internet can serve as an effective marketing tool in tourism [1]. The planning and development of hotel and resort websites is increasingly pertinent, including their evaluation, to ensure that the interface with customers is as appealing and informative as possible and to transform visitors into buyers [2].

Hence, online presence is essential for hotelier and the quality of websites can influence customer's response towards the products and services. In the case of five start hotels, there are many studies to evaluate website performance based on functionality, usability and other factors, much less on the amount of different information available to the consumers globally. In the near future by using Big Data it is expected that hotel websites will be dynamic, they will adapt themselves on-the-fly, showing personalized information to each consumer. Different consumers will have different websites (information' available) from the same hotel. However the scenario is entirely different in Saudi Arabia where no such scholarly literatures are available at present. This motivates the authors to investigate the state of affairs of hotel website in the premium and luxury segment of the hospitality industry in Saudi Arabian industry for the purpose of research.

\section{OVERVIEW OF WEB MARKETING AND HOSPITALITY INDUSTRY IN SAUDI ARABIA}

Web site is considered as one of the most important identities in the new age hotel marketing. Potential and present customers as well as general public scan detailed information on hotel products, services, offers, contact numbers, location and special assistance from the hotel web site. It is the connecting link between hotel management and customers. It is important for an hotelier to integrate both of their website and the blog, so that it is easier for the customers to access. Mobile marketing, Video marketing which is most popular with advent of YouTube and social media marketing are the key to reach target group especially among the youth. Content marketing is a long term web marketing strategy where the main focus is to build a strong and long lasting relationship with the audience by giving them a good quality content that relevant with hospitality products or hoteliers' brand. In short, various Mobile technologies, Apps and Platforms provided opportunities for customers to buy hospitality products and services as per their choice and convenience [3].

Key to success of web marketing is to have a good web site itself. This paper explores how Saudi Arabian five star hotels are tuning with this digitalization. Hence the focus of the study was to analyze the hotel web sites of premium five star hotels in the area chosen for the purpose of the study namely Riyadh, Jeddah, Makkah, Madinah, Abha and Jazan Regions of Saudi Arabia. . Because a hotel's website plays an essential role in marketing the property, including online booking $[4,5]$, the website's content and features are an important management consideration. In-depth website analysis make the hoteliers to improve their website rankings \& online visibility through SEO, social media, usability and much more.

Tourism activities in Saudi Arabia are centered on the holy cities of Makkah and Madinah, the western part of the kingdom. The hospitality market for both cities is closely related as pilgrims perform Hajj or Umrah in Makkah and then travel to Madinah to visit Al Masjid An Nabawi (the Prophet's Mosque).Religious tourism should flourish as the Kingdom completes expansion of the Holy mosques and Colliers expects visitors to Makkah and Madinah to reach $25 \mathrm{mn}$ by 2025 from just over $19.5 \mathrm{mn}$ in 2018 . About $63 \%$ of the hotel supply in Makkah and $66 \%$ in Madinah is three stars and above, highlighting that there could be oversupply of premium hotels which may explain the growing popularity of branded economy hotels and apartments in both the regions. There are 250 tour operators in the kingdom, which cater primarily to religious tourism.

The hospitality sector in Makkah can be classified into two parts; the high-quality international branded luxury hotel market and unbranded \& unfurnished hotels. In Makkah, the total supply of rooms was 127,209 at the end of February 2019, with $23 \%$ (five star), $21 \%$ (four-star), and 19\% (three-star). Major five star hotels present in Makkah include Swissotel Makkah, Moevenpick Hotel \& Residence Hajar Tower Makkah, Pullman ZamZam Makkah, Royal Dar Al Eiman, Al Marwa Rayhaan, Hilton Makkah Hotel, Al Marwa Rayhaan by Rotana, Hotel Al Shohada, Raffles Makkah Palace, Makarim Umm AlQura Hotel, Elaf KindahMakkah, Dar Al Ghufran, Makkah Clock Royal Hotel, and Intercontinental Dar Al Tawhid Makkah.

In Madinah, the total supply of rooms was 66,536 at the end of February 2019, with 37\% (fivestar), 26\% (four-star), and 23\% (three star). Major local hotel brands such as Al Ansar Hotels Company and 
Mubarak Group have a strong presence in the region. Over the last two years, both Riyadh and Jeddah have been drawing more hotel groups and brands - both local and international - on the back of major infrastructure projects and easing visa requirements. According to Colliers International, Riyadh's hotel inventory in 2019 includes 119 properties comprising 16,441 rooms, while Jeddah's inventory stands at 92 hotels with 11,276 rooms. Riyadh is quickly becoming an exhibition hub and is home to some of the GCC's newest entertainment shows and festivals. These developments are unique to Saudi Arabia, and the country will continue to grow and diversify its touristic offering while maintaining its unique identity.

The study produced by ATM's research partner Colliers, found that religious tourism in the Kingdom is still driving demand, with 40,000 rooms opened during 2018, with a further 40,020 guestrooms in 89 projects under construction in 2019 - compared to 35,050 rooms in the UAE. In 2018, Saudi Arabia set the stage for expanding to leisure tourism, as it pursues targets of 30 million visitors annually by 2030 .

Business tourism is growing fast on the back of strong economic growth and the government's focus on developing other segments of the economy. In 2019, this is concentrated in the three major cities of Saudi Arabia, which are; Riyadh, Jeddah and Al-Khoba. Premium hotels dominate the supply in the three cities and given the increasing number of business tourists in the cities, luxury brands should continue to prosper. In addition, there is considerable potential for the economy hotel segment, as the growing Asian travelers are more price-sensitive. Branded residences are also gaining popularity among the wealthier tourists (mainly business travelers).

The MICE (Meeting, Incentives, Conferences and Exhibitions) segment in the GCC region has expanded significantly over the past couple of years backed by growing number of MICE facilities and probusiness and tourist-friendly policies. According to the International Congress and Convention Association (ICCA), the number of international association meetings in the Middle East has doubled each decade in the last 50 years, and more than tripled in the last 10 years. The MICE industry in the region is set to expand in the near future, as the region continues to attract high-profile global events and continues to invest in building infrastructure.

Riyadh, the capital of KSA, is a prime destination of corporate tourism. The four and five star hotels constituted $86 \%$ of the total rooms at the end of 2018 , indicating that luxury hotels are the first choice of business travelers. A large number of hotels in Jeddah were re-categorized in 2018 in line with the SCTA's efforts to follow global standards. It is notable that four and five-star hotels dominated the market in Jeddah with expected $83.5 \%$ of the available supply in 2019 . The occupancy rates have historically been higher in Jeddah as compared to Riyadh. Following reforms in 2018 and the relaxation of visa regulations, Saudi Arabia is poised to capitalize on these factors as it nurtures a vibrant leisure and entertainment sector, supported by a new generation of hotels across the country. Saudi Arabia is expected to see a vast expansion of its hotel and resort inventory, along with a steep increase in airport passengers, as Crown Prince Mohamed bin Salman continues to drive economic and social reforms, including direct investment in tourism.

This paper explored a framework for the characterization of hotel websites, focusing on the amount of information available to the consumer in each website, which was applied in a case study during the December 2018 and April 2019 to the websites of five-star hotels that operate in the main tourism region of Saudi Arabia namely Riyadh (33 per cent of the sample), Jeddah (36 per cent of the sample), Pilgrim centres of Holi Makkah (14 per cent of the sample ) and Holi Madinah (11 per cent of the sample) along with Abha and Jazan (3 per cent each of the sample population covered in the study).

\section{LITERATURE REVIEW}

According to the U.S. Department of Health and Human Services [6], website evaluation can be defined as the act of determining a correct and comprehensive set of user requirements, ensuring that websites provide useful content that meets users' expectations and setting usability goals [7]. This conceptualization is, in reality, not new. The World Tourism Organization [8] has developed a set of practices for the development of websites in tourism organizations, taking into account the role they intend these websites to play within their marketing strategies, in order to increase demand, sales and revenue; reduce costs and response time and improve communications and customer relationships.

Numerous studies have analyzed the features of hotels' websites, but most have focused on breadth of features without considering their technical depth Murphy et al., [9] categorized thirty-two different site features into four groups: promotion and marketing interactivity and technology, service information, interactivity and technology.But they did not explore the technical depth of each category and was confined only to local hotels in USA. To investigate the depth (or technical maturity level) of hotel websites, we applied the extended Model of Internet Commerce Adoption (eMICA)

The original MICA is a matrix established by Burgess and Cooper [10] for classifying the interface of e-commerce by the stages of its development. The extended model developed by Ping-Ho Ting et al., in 2013 deepens the analysis of each stage into more detailed layer [11]. They combined peer-reviewed 
content analysis with the eMICA model for assessing the development of hotel websites in terms of both content breadth and technical depth. They analyzed the websites of a sample of the top 100 independent hotels listed in Travel and Leissure 2010 magazine across Europe Americas, Asia and Africa leaving Middle east region out of the reach of the study. Hence we extended the study by adapting the eMICA model for the five star hotels of Kingdom of Saudi Arabia in 2019.

While developing these websites, in order to ensure that the product attains the desired quality, designers must consider usability: the website must take into consideration consumer' profiles and their satisfaction when using the website [12]. However, these are not the only factors to take into account Chiou, Lin, and Perng [13] recommended other dimensions, including interactivity, navigation, website marketing, place, product, price, promotion, customer relations, accessibility and speed. In 2010, Law, Qi, and Buhalis observed that the evaluation of websites is an emerging research area that has no globally accepted definition and that there is no universally accepted technique or standard for website evaluation.

Marketing and communication design on a website may identify what works for its target market. This can be an age group or particular strand of culture; thus the designer may understand the trends of its audience. User understanding of the content of a website often depends on user understanding of how the website works. Much of the user experience design and interactive design are considered in the user interface design. A static website stores a unique file for every page of a static website. Each time that page is requested, the same content is returned. This content is created once, during the design of the website. It is usually manually authored, although some sites use an automated creation process, similar to a dynamic website, whose results are stored long-term as completed pages.

Dynamic websites are generated on the fly and use server-side technology to generate webpages. They typically extract their content from one or more backend databases: some are database queries across a relational database to query a catalogue or to summarize numeric information, others may use a document database. Web analytics is the measurement, collection, analysis and reporting of web data for purposes of understanding and optimizing web usage. However, Web analytics is not just a process for measuring web traffic but can be used as a tool for business and market research, and to assess and improve the effectiveness of a website.

According to Ip, Law, and Lee [14], studies on website evaluation fall into two categories - quantitative and qualitative - where quantitative researches usually generate performance indices to represent overall website quality, while qualitative studies assess websites' quality without the use of numerical scores. More recently, new models and strategies have become available. For example, Escobar-Rodríguez and CarvajalTrujillo [15] presented a study identifying the strategies used by Spanish hotel websites and analyzing the relationship between the size of hotels and their website strategy.

Schmidt, Cantallops, and Dos Santos [16] indicated that the most important determinants for successful website marketing and promotion were quality of information and assurance of website security. Although online reviews have gained considerable importance [17], the website must effectively present the hotel's features. In a study of four and five star hotels in Turkey, Baloglu and Pekcan [18] found that different types of hotels have different emphasis on the design characteristics (i.e., interactivity, navigation, and functionality) and site marketing practices. Site feature differences also are found between chain hotels, which focused on navigating the characteristics of the hotels in the group, and independent hotels, which stressed the introduction of the hotel by an interactive interface [19]. Chung and Law [20] applied five dimensions to measure the efficacy of Hong Kong hotel websites through content analysis.

Further, Zafiropoulos and Vrana [21] proposed an evaluation framework for hotel websites that categorizes web information services into six dimensions by applying hierarchical cluster analysis. They used this to compare the performance of the top 25 hotel websites in Greece. In 2008, Maswera, Dawson, and Edwards [22] carried out two surveys. The first consisted of an analysis of the nature and extent of e-commerce adoption by tourism organizations in four countries of sub-Saharan Africa.

In the second, in the U.S. and Western Europe. These authors presented an exhaustive list of characteristics of e-commerce websites, as well as a descriptive analysis of the data collected. Later, in 2009 [23], explained how tourism organizations from the subSaharan African countries studied could develop their websites into marketing tools and how they could overcome impediments to e- commerce adoption and usage.

Kim and Fesenmaier [24] analyzed the key elements in information on first impressions of tourism destination websites. Their results confirmed that, at that time, the majority of state tourism websites in the U.S. met the basic needs of travel information seekers in terms of the characteristics of format and usability, but that other design characteristics, such as credibility, inspiration, involvement and reciprocity related design elements, were not perceived as favorably. 
Ip, Law, \& Lee, [25] that, as human judgment is often uncertain and vague, the use of a fuzzy set theory approach enables evaluators to capture decision makers' uncertainty. Their results indicated that 'reservation information' is the most important criterion for website functionality. Line and Runyan [26] reviewed hospitality marketing research published in four top hospitality journals from 2008 to 2010 and concluded that, at that time, more marketing researches were needed on social media and about Web 2.0 in the tourism sector.

Díaz and Koutra [27] evaluated persuasive features of hotel chains' websites. They separated hotel chains into categories and then proceeded to segment hotel chains into types according to the persuasiveness of their websites, using latent class segmentation. Salavati and Hashim [28] used the content analysis technique and identified 48 different features of the websites of 75 Iranian hotels and concluded that the results indicate that page ranking and the hotel star rating are significantly related to website performance. Bronner and Hoog [29] analyzed the role of web-based information in tourism measure one-time interactions through a longitudinal study.

\section{THE STUDY}

The definition of hotel website indicators and dimensions involved in identifying features and characteristics of hotel websites, designated as 'indicators'. With these indicators identified, the next step consisted of grouping them into 'dimensions'. Each dimension comprises a group of indicators with the same purpose/goal/function. This step also included the formation of 'dimension groups' that integrate related dimensions inventoried by analyzing which new characteristics/features appeared on at least two websites of hotels within the five star segment covered in this study. The authors selected Reservation functionality dimension, Surrounding information dimension, Website functionality dimension, CRM functionality dimension, Website navigation dimension, Social network dimension, Product information dimension, Website management dimension and Payment method dimension for the purpose of evaluating the website.

The list given below only presents the dimensions proposed by the below authors (authors: dimensions), including the indicators they propose (along with others) integrated with empirical contributions:

Chung and Law [20] facilities information, customer contact information, reservation information, surrounding area information and management of website; Baloglu and Peckan [18] interactivity, navigation, functionality and website marketing features; Zafiropoulos and Vrana [21]: information facilities, guest contact information, reservation/price information, surrounding area information, management of the website and company profile; Maswera, Dawson, and Edwards [30, 22]: corporate information, product information, non-product information, CRM, reservations and payment;(e) Schmidt et al., [16]: promotion, price, product, multimedia, navigability, reservation system, security and customer retention and privacy(f) Hernandéz et al., [31]: accessibility, speed, navigability and content quality and Chiou et al., [13]: place, playfulness, product, price, promotion and customer relations.

The reason to choose the above authors are due to be the authors/papers with a high number of citations, as well as to be the authors/papers well recognized by the peers. A sample of such dimensions were given below with indicators identified under that dimension for a quick glance and listing all nine functionalities and their indicators would make this paper more bulky too much space consuming and hence avoided.

\begin{tabular}{|c|c|}
\hline Multilanguage & Presents more than one language other than Arabic. \\
\hline Search engines & Search engine available in the hotel website. \\
\hline Help/online assistance & Link for a direct contact with the online assistance. \\
\hline Sitemap/index Page & Presents a sitemap and/or an index page. \\
\hline \multicolumn{2}{|l|}{ Website Functionality } \\
\hline Background color & $\begin{array}{l}\text { Presents a color in the background that makes a harmonious contrast } \\
\text { with other elements. }\end{array}$ \\
\hline Background image & Shows a background image of the hotel. \\
\hline Date last updated & Displays the last date of the website update. \\
\hline $\begin{array}{l}\text { Do you have to scroll down on first } \\
\text { page? }\end{array}$ & $\begin{array}{l}\text { The first page does not need to scroll to show the whole page } \\
\text { (resolution of } 1024 \times 768 \text { ). }\end{array}$ \\
\hline What's new? & There is available information about hotel news. \\
\hline Variety of information & Shows information about the region events and heritage. \\
\hline Detailed information & $\begin{array}{l}\text { Presents information useful and complete about the facilities, services } \\
\text { and amenities. }\end{array}$ \\
\hline Ease of access to website & Simply and quickly to find the hotel website. \\
\hline \multicolumn{2}{|l|}{ Website Navigation } \\
\hline Links to others & Presents links to other organizations (restaurants, shops, museums). \\
\hline $\begin{array}{l}\text { Consistent } \quad \text { navigation/logical } \\
\text { structure }\end{array}$ & $\begin{array}{l}\text { Presents a clear idea about what to find in the website and how to find } \\
\text { it. }\end{array}$ \\
\hline
\end{tabular}


So, this research will essentially be able to fill in a spot on the map by conducting a study on Saudi Arabia that is similar to the studies conducted by Atay et al., [32] on Turkey or by Salvati and Hashim [28] on Iran. A content analysis method has adopted for the purpose of the research. More specifically, the authors adopted the same tools that were utilized in Ting et al., [33] study. This consists of the eMICA tool along with a schema for applying checklist criteria across various dimensions. The fundamental reason for this study was how far Saudi Arabian hoteliers' utilized their hotel website as a new age marketing communication tool for connecting with their profitable customers effectively with credible offers and valuable messages.

The basic concept of Burgess and Cooper's [10] MICA was to classify website interfaces according to a three-stage rubric, namely, promotion, provision, and processing. In the eMICA model the functionalities were defined by the stages of technological development as seven operational variables as given under a)Interactivity means online availability, offline reservation, worldwide reservation phone number, special request forms, general description/history, map, transport information, travel guides, awards, the latest news, address, fax, phone, email, feedback form, guest book, chat or discussion forum, newsletter, press releases, RSS, FAQ, privacy policy. This has been defined further in the study with 24 items/properties available in the website of the hotel under study. b) Navigation means important organization e-mail hyperlink, sitemap, e-mail hyperlink, tourism search engine, keyword search. This has been defined further in the study with 5 items/properties available in the website of the hotel under study. c) Functionality means important organization contacts, currency converter, flash animation, membership system, download facilities. This has been defined further in the study with 5 items/properties available in the website of the hotel under study. (d) Marketing means prices or cost of products and services, packages and promotions, dining, photos or photo album, video, itineraries information, awards, special offers, e-brochure. This has been defined further in the study with 10 items/properties available in the website of the hotel under study. e) Service means check-in and check-out time, hotel rooms and suites, activities and entertainment, dining, conference and meeting facilities, online purchase or gift store, map, itineraries information, e-brochure. This has been defined further in the study with 10 items/properties available in the website of the hotel under study. f) Innovation means digital signature and encryption, view or cancel reservation, virtual tours, travel schedules and plans, Web 2.0 tools. This has been defined further in the study with 5 items/properties available in the website of the hotel under study and g) Online processing means online availability, online reservation, currency converter, view or cancel reservation, payment options, special request forms, online purchase or gift store, local time, multi-language support, travel schedules and plans, membership system, chat or discussion forum, press releases, RSS, Web 2.0 tools, share this page. This has been defined further in the study with 12 items/properties available in the website of the hotel under study.

The Extended Model of Internet Commerce Adoption (eMICA) as framed by Doolin, Burgess, and Cooper [34] had 3 stages:

\section{Stage 1: Promotion}

Layer 1: Basic information which includes global reservation phone number, address, fax and phone.

Layer 2: Rich information which includes prices and cost of products and services, important organization contacts, check-in and check-out time, general description and history, awards and e-mail.

\section{Stage 2: Provision}

Layer 1: Basic interactivity which is represented by features such as offline reservation, packages and promotions, important organization email hyperlink, currency converter, hotel rooms and suites, activities and entertainment, dining, conference and meeting facilities, photos or photo album, map, transport information, travel guides, e-mail hyperlink and share this page.

Layer 2: Medium interactivity which is represented by Online availability, payment options, special request forms, sitemap, itineraries information, feedback form, guest book, membership system, FAQ, tourism search engine, special offers, keyword search, download facilities and e-brochure.

Layer 3: High interactivity which is represented by Video, flash animation, virtual tours, multi-language support, travel schedules or plans, chat or discussion forum, newsletter, Rich Site Summary (RSS) and Web 2.0 tools.

\section{Stage 3: Processing}

Advanced applications: Digital signature and encryption, online reservation and facility for interactive brokering.

\section{DATA ANALYSIS}

The indicators, dimensions and dimension groups were based on the literature and complemented with an empirically derived inventory. We adapted the eMICA analysis because hotels on different regions of KSA may not be equally mature on eMICA's three stages Therefore, we tailored the eMICA model for the premium and luxury five star hotel industry that provides interpretation to fill in the gap of hotel emarketing strategy through distinct web design. 
The authors chose to analyze five star category hotel websites (42). The sample consisted of fifteen hotels from Jeddah (36 per cent), fourteen hotels from Riyadh (33 per cent), six hotels from Makkah, five hotels from Madinah and one hotel each from Abha and Jazan. Based on literature survey, we evaluated the following functional features: interactivity, navigation, functionality, marketing, service, innovation, online processing, as well as the eMICA stage of technical development. The adapted eMICA model's layers of complexity comprised a total of fifty-nine features for analysis.

Multiple Correspondence Analysis (MCA) was applied in this study to determine the distinguishing features of the hotels on each region. The analysis presented the corre- lations between the hotels' location and the features typical of that hotel. For the content analysis, five experts with an Information Technology background coded the features separately, while another three experts resolved disagreements. The mutual agreement and the reliability (indicated by Cronbach's $\alpha)$ of the coding outcome were as follows: $0.94(\alpha 0.95)$ for Jeddah region, $0.93(\alpha 0.96)$ for the Riyadh region $0.92(\alpha 0.94)$ for Makkah region, and $0.91(\alpha 0.92)$ for Madinah region. Twelve features were determined to have dual characteristics by all eight experts, such as "online availability," categorized into both online processing and interactivity dimensions, and dining which can be seen as both as a service for hotel guests and as a marketing tool to attract non-lodging customers.

\section{MAJOR FINDINGS}

This section has divided into two parts:

\section{Website Characterization}

Website management dimension (68.1\%):

There was no predefined/standard number of languages used per website/hotel. Hotels fluctuated from 2 languages $(83.3 \%)$ to 4 different languages (14.4\%). We defined multi-language hotels as those with at least 2 different languages available on their website, and all of them met that definition. It was observed that only a few websites named the web designer (7.2\%), and almost all the websites showed the web host (83.3\%). It needs to be noted that the majority of the websites showed terms of use $(95.2 \%)$, search engines $(97.6 \%)$ or sitemaps $(90.5 \%)$. Only a few websites had online assistance $(4.8 \%)$.

Website navigation dimension (29.2\%): Only a few websites presented links to others $(14.4 \%)$ or the tourism information office $(2.4 \%)$, but almost all the hotels presented the information as updated $(83.3 \%)$. In generally, the majority $(77.1 \%)$ of the websites had a consistent navigation/logical structure, $51.4 \%$ of the websites had intuitive navigation and $68.6 \%$ of the websites presented a friendly interface, from which can be concluded that there was still much work to be done in this area.

In this dimension also were considered features associated with new technological applications and innovative characteristics that were present on some websites, such as to watch images from the hotel using a webcam (14.4\%), change the font size (7.2\%), download brochures or information about the hotel $(12 \%)$, view pictures that show the hotel in an aerial view $(2.4 \%)$, find a flight when travellers need to know something about their plane departures and arrivals $(14.4 \%)$ and take a $360^{\circ}$ tour of the hotel $(2.4 \%)$.

Website functionality dimension (18.6\%): Almost all the websites presented problems in this category, since a few did not have a background color $(9.6 \%)$ or a background image $(24 \%)$ and also, in some of them, the user could not scroll down the first page when using a resolution of $1024 \times 768$ (21.6\%). Only $19.2 \%$ presented the feature 'What's new?', which represented an extremely low percentage. This feature can lead to an increase in the frequency of views of the websites or to further consultations of the news that the websites offer tourists.

Social networks dimension (49.4\%): All the hotels already had an online presence. The social network included the most was Facebook (96\%), followed by Twitter (91.4\%) and WhatsUp (84\%). However, there were social networks that were not included by many hoteliers, as in the case of LinkedIn (24\%), Google+ $(21.6 \%)$, Blogger $(16.8 \%)$ and Trip Advisor (12\%) despite being included on some hotel websites still had a quite low percentage of importance attributed to them by consumers when choosing the characteristics of their intended vacation destinations.

Product information dimension (35.9\%): There were some features considered by all (100\%) hotels in the study, such as a brief description, a photo gallery, hotel facilities, room facilities, dining facilities, wedding and conference facilities. On the other hand, there were features not yet considered by the majority of them, such as price $(60 \%)$, trip or mileage reward points $(7.2 \%)$, FAQs $(9.6 \%)$ and information about shops and gifts $(2.4 \%)$.

\section{Surrounding information dimension} (24.3\%): There were already many websites that displayed maps $(72 \%)$ and presented information on how to get there $(60 \%)$. However, many did not disseminate enough information about the weather (2.4\%), local transportation information (2.4\%), restaurants in the surrounding area $(7.2 \%)$ and shopping (19.2\%), routes and itineraries in the region $(36 \%)$ or medical and health information $(2.4 \%)$.

Customer relationship management dimension (29.1\%): This includes the features that 
encourage relationships to develop with customers, which can enhance and strengthen relationships with hotels in order to maximize customers' loyalty of relevance because it is more expensive to attract new customers than to keep existing ones. All hotels in the study presented an email address and contact details. In terms of processes and concerns about customer loyalty, there was still much to do. In this dimension, the majority of websites presented promotions and special offers (36\%), group promotions (89 \%), newsletters $(72 \%)$ and request forms $(21.6 \%)$. On the other hand, there are special features that can be included in hotel websites including, among others, customer online surveys $(2.4 \%)$, to understand if customers are satisfied with the service; online guest books $(9.6 \%)$, to enhance customers' experience and feedback; events and festivals calendars (14.4\%), to show the existence of events in proximity to the hotels, to encourage customers to choose one hotel over another hotel nearby; belonging to the same competitive set complaint forms $(7.2 \%)$, to get the opinion of clients and detect where service can be improved and special programs $(9.6 \%)$, to encourage website visitors to become future clients.

Reservation functionality dimension (2.4\%): In this group, there were higher percentage of websites that lacked cancellation policies $(91.4 \%)$ or the ability to cancel online $(72 \%)$. This does not help to create an image of the safety and transparency of information about the hotels.

Payment method dimension (68.5\%): Again $48 \%$ did not refer to the possibility of using a debit card but accepts Master and Visa credit cards and nearly $89 \%$ showed a currency converter.

\section{The Evaluation of the Development of Stages for Hotel Websites based on eMICA Framework}

It can be seen from the data analysis that hotels on all five regions had implemented first stage (promotion) applications with all continents at 96 percent or above for basic information. For the next layer, rich information, Madinah and Makkah regions hotels were at the leading position with an implementation ratio of 95 percent. This analysis again showed Riyadh and Jeddah region hotels' high web interactivity in terms of Stage 2 (provision). Once again we see that the business travelers in prefer the interface to contain provisions for mutual communication.

At Stage 3 (processing), except for Riyadh region with its low implementation rate of 13 percent, hotels showed reasonable strength, as the other five regions had up to 5 percent implementation of the Stage 3 features. Although processing is the most mature stage in this model, the provision stage has experienced dramatic technological progress in recent years, and subsequent study may see a redefinition of the stages. Moreover, the medium interactivity and high inter- activity features are add-ons that may increase potential sales but are not (currently) mandatory in terms of guests' expectations.

The authors also observed the practical limitations such as the cost of necessary bandwidth for high-speed interactivity. Some hotel operators may be hesitant to make additional investments to add web features beyond fundamental functionality. The lower implementation ratio of the advanced features reveals the uncertainty of investment efficiency for hotels everywhere.

A chi-square homogeneity test found twelve features that significantly distinguished the hotels' websites as shown in below:

The Significant Factors Extracted from Chi-Square Homogeneity Test

\begin{tabular}{|r|l|}
\hline 1. & Online availability \\
\hline 2. & Awards \\
\hline 3. & Travel tips \\
\hline 4. & Keyword search \\
\hline 5. & Currency converter \\
\hline 6. & Packages/promotion \\
\hline 7. & Dining \\
\hline 8. & Web 2.0 tools \\
\hline 9. & Online reservation \\
\hline 10. & Payment options \\
\hline 11. & Multilanguage support \\
\hline 12. &
\end{tabular}

Note: All twelve factors are significantly different at $p$ .05

The above twelve features were used in our correspondence analysis to investigate the distinct characteristics of the hotels on each region. The major distinguishing characteristics for Riyadh and Jeddah hotel websites are online availability and currency converter, online reservation, payment options, conference and meeting facilities, and multi-language support. Standouts on Abha hotel websites are their online tour to nearest places like Rijal Alma-300 year old Saudi Village, Al habalah suspended village and cable cars to Urean Mountains and Web 2.0 tools. On Riyadh and Jeddah region s hotel websites, the strong features are facility for key word search and expansion of Meeting, Incentives, Conferences and Exhibitions (MICE) segments and Makkah and Madinah regions hotels websites perform well in the features of spiritual travel, travel tips, packages and promotions and dining.

Using the terms determined in the content analysis, the quantitative evaluation of the websites involved a tally of the frequency of each of the fiftynine features. We found 49.8 features well implemented in Makkah region hotel websites, 46.3 features in Madinah region hotels' sites, 46.1 in the Jeddah and Riyadh region hotels, and 32.2 features in the Abha and Jazan hotel sites. Jeddah and Riyadh 
region sites showed leading performance, with online processing and innovation. We judged that the Makkah and Madinah region hotels needed to improve by adding the following features: newsletter, RSS (Rich Site Summary), virtual tours, and Web tools. Sites in the Jazan Abha region hotels could improve their sites with travel guides, travel tips, FAQs, and keyword search routines. We thought that Riyadh and Jeddah region hotels should include such features as privacy policies, digital signature encryption, and the ability to view or cancel reservations.

Navigation was similar for all. It can be noted that the differences on website performance among these five regions mainly occurred in advanced layers of both promotion and provision stages. We believe the interactivity found on Riyadh and Jeddah region hotels' websites is a reflection of the country's cultural approach to detail oriented service. This analysis does not imply that Riyadh and Jeddah region hotels are more developed in the cyber technique, but its hotels are responding to a more demanding market in the stages of promotion and provision through web communication.

\section{CONCLUSION}

It may be established from the findings of the study that Saudi Arabian five star hotel websites are yet to utilize the potentiality of their website as a tool for marketing hotel product and services as the mean value of 9 functionality dimensions were only 36.2 per cent only. That means more than 63 per cent is underutilized. This may be due to lack of intense competition among various destinations and brands. This is further supported by their poor mean score in reservation functions $(2.4 \%)$, website functionality $(18.8 \%)$ and product information $(35.9 \%)$.

From our study, it is possible to conclude that the hotels studied pay more attention to dimensions such as website functionality, reservations and product information, which, in our opinion, can be explained by hoteliers needing to present, publicize and sell their rooms. In addition, it is important to present a mechanism that allows consumers to conclude their purchase or make reservations. In these situations, the characteristics associated with the purchase dimension can make the difference if customers have sufficient, transparent information about how to make reservations.

This study also evaluated the features of five star hotels' websites from five regions of KSA, based on an adaptation of eMICA, which provided in-depth hotel web site evaluation. Thes study results suggest that the hotels in different regions strive to fulfill the guest's online experience by going in different directions. The study found that the development of the most of the websites we studied fell into the second stage of eMICA model, with the exception of Jazan and Abha regions hotels websites, which were in the first stage of development.
The analysis identified commonalities and differences of the features associated with these hotels' websites. Results demonstrate that the fundamental features (e.g., marketing, service, and basic and rich information in the promotion stage) are vividly implemented and regional in nature.

\section{MAJOR RECOMMENDATIONS WAY FORWARD}

The authors offered the following suggestions based on the research findings for further hotel website improvement:

1. Regarding navigation strategies, we suggest that the hotels optimize their websites to enhance the power of travel search engines and keyword search. Travelers would benefit if the hotel websites can provide such information to make one-stop shopping possible and facilitate tourism development in the destination.

2. In terms of web functionality, we recommend that hotels add a price information so that consumers can get an immediate idea of the cost of their stay. This will also facilitate bookings.

3. (iii)Likely innovations based on this study include virtual tours, travel schedules and plans, and Web 2.0 tools, if sites do not have them already. The virtual tours would familiarize the customers with the facilities and surrounding environment, which would enhance the guest's virtual experience and intention to stay in the hotel. Extra revenue can be gained through providing the itinerary arrangement and attraction and shopping information to the travelers. Using Web 2.0 tools such as Twitter and Facebook can help to promote the hotel globally by sending the most updated information to the customers.

4. With regard to online processing, we suggest that hoteliers add interactivity features so that customers' problems can be resolved immediately and save the cost of communication such as telephone and fax

5. For future research, the authors suggested the following:

- Applying this framework to the same group of hotels in other regions to analyze differences and to see if there are differences in websites that depend on technological and socialeconomic realities of regions.

- Correlating the information presented on websites with the number of bookings in hotels.

- Applying the framework to different groups of hotels in the region: lower rating hotels (fourand three-star, or others) and other kind of accommodations

- Interviewing the hotel managers and the website consumers to analyze the relationship between their strategies, website business models and website information performance in order to adjust our indicators and 
information dimensions to their answers.

- Including eye-tracking technology to analyze websites, thereby creating another dimension and comparing results and

- Taking care with accessibility rules when developing websites, forming yet another dimension and combining all values to reach conclusions about new trends - if they change the results or have other impacts

\section{IMPLICATIONS FOR ACADEMIC RESEARCH}

Overall, three major contributions of this article are as follows. The study (1) establishes an integrated method to evaluate the development stages of Saudi Arabia's hotel websites and to depict the relationships between the features and the regions, (2) analyzes the distinct characteristics of the hotel websites in each regions under study in a holistic qualitative technique with a clear direction for further improvement, and (3) provides a solid and objective view of research into website analysis by applying peer reviewed content analysis.

\section{ACKNOWLEDGEMENT}

Authors would like acknowledge the moral supports and encouragements of Jazan University, CBA and DR Ali Medabesh Dean, College of Business Administration, Jazan University, Ministry of Education KSA for publishing this work.

\section{REFERENCES}

1. Buhalis, D., \& Law, R. (2008). Progress in information technology and tourism management: 20 year on and 10 years after the internet: the state of eTourism research. Tourism Management, 29(4), 609-623.

2. Ramos, C., \& Perna, F. (2009). Information system for tourism activity monitoring and forecasting indicators as an experience for Portugal. Tourism and Hospitality Research, 9(4), 277-289.

3. Shajahan, S., \& Khalufi, N. (2018). A Study on consumers perception of Mobile marketing communications on social media in USA. Journal of Mass communication and Journalism USA, 386,8(4).

4. Liao, C., To, P., \& Shih, M. L. (2006). Website practices: A comparison between the top 1000 companies in the U.S. and Taiwan. International Journal of Information Management, 26(3): 196211.

5. Tso, A., \& Law, R. (2005). Analysing the on-line pricing practices of hotels in Hong Kong. International Journal of Hospitality Management 24(2): 301-307.

6. US Department of Health and Human Services. (2006). The health consequences of involuntary exposure to tobacco smoke: a report of the
Surgeon General.

7. Law, R., Qi, S., \& Buhalis, D. (2010). Progress in tourism management: A review of website evaluation in tourism research. Tourism Management, 31, 297-313.

8. WTO. (2001). Practical guidelines for tourism destinations and businesses. [Online] Retrieved from

http://pub.unwto.org/WebRoot/Store/Shops/Infosh op/Products/1210 /1210-1.pdf.

9. Murphy, J., Forrest, E. J., Wotring, C. E., \& Brymer, R. A. (1996). Hotel management and marketing on the internet: An analysis of sites and features. Cornell Hotel and Restaurant Administration Quarterly, 37(3), 70-82.

10. Burgess, L., \& Cooper, J. (1999). MICA: A model for classification of business adoption of Internet commerce. Proceedings of the 12th International Bled Electronic Commerce Conference, Bled, Slovenia, 46-58.

11. Ting, P. H., Wang, S. T., Bau, D. Y., \& Chiang, M. L. (2013). Website evaluation of the top 100 hotels using advanced content analysis and eMICA model. Cornell Hospitality Quarterly, 54(3), 284 293.

12. Nysveen, H., \& Lexhagen, M. (2001). Swedish and Norwegian Tourism Websites: The Importance of Reservation Services and Value added Services. Scandinavian Journal of Hospitality and Tourism, 1(1), 38-53.

13. Chiou, W., Lin, C., \& Perng, C. (2010). A strategic framework for website evaluation based on a review of the literature from 1995- 2006. Information \& Management, 47, 282-290.

14. Ip, C., Law, R., \& Lee, H. A. (2011). A review of website evaluation studies in the tourism and hospitality fields from 1996 to 2009.International Journal of Tourism Research, 13, 234-265.

15. Escobar-Rodriguez, T., \& Carvajal-Trujillo, E. (2013). An evaluation of Spanish hotel websites: Informational vs. relational strategies. International Journal of Hospitality Management, 33, 228-239.

16. Schmidt, S., Cantallops, A. S., \& Dos Santos, C. P. (2008). The characteristics of hotel websites and their implications for website effectiveness. International Journal of Hospitality Management, 27(4): 504-16.

17. Anderson, C. K. (2012). The impact of social media on lodging performance, Cornell Center for Hospitality Research. Cornell Hospitality Report, 12(15).

18. Baloglu, S., \& Pekcan, Y. A. (2006). The website design and Internet site marketing practices of upscale and luxury hotels in Turkey. Tourism Management, 27(1): 171-76.

19. Au Yeung, T., \& Law, R. (2004). Extending the modified heuristic usability evaluation techniques to chain and independent hotel websites. International Journal of Hospitality Management, 
23(3): 307-13.

20. Chung, T., \& Law, R. (2003). Developing a performance indicator for hotel websites. International Journal of Hospitality Management, 22(1): 119-25.

21. Zafiropoulos, C., \& Vrana, V. (2006). A framework for evaluation of hotel websites: the case of Greece. Information Technology \& Tourism, 8, 239-254.

22. Maswera, T., Edwards, J., \& Dawson, R. (2008). E-commerce adoption of travel and tourism organizations in South Africa, Kenya, Zimbabwe and Uganda. Telematics and Informatics, 25, 187200.

23. Maswera, T., Edwards, J., \& Dawson, R. (2009). Recommendation for E-commerce systems in the tourism industry of Sub-Saharan Africa. Telematics and Informatics, 26, 12-19.

24. Kim, H., \& Fesenmaier, D. R. 2008. Persuasive design of destination websites: An analysis of first impression. Journal of Travel Research, 47(1), 313.

25. Ip, C., Law, R., \& Lee, H. A. (2012). The evaluation of hotel website functionality by fuzzy analytic hierarchy process. Journal of Travel \& tourism Marketing, 29, 263-278.

26. Line, N. D., \& Runyan, R. (2012). Hospitality marketing research: recent trends and future directions. International Journal of Hospitality Management, 31(2), 477-488.

27. Diaz, E., \& Koutra, C. (2013. Evaluation of the persuasive features of hotel chains websites: A latent class segmentation analysis. International Journal of Hospitality Management, 34, 338-347.

28. Salavati, S., \& Hashim, N. H. (2015). Website adoption and performance by Iranian hotels. Tourism Management, 46, 367-374.

29. Bronner, F., \& Hoog, B. (2016). Travel websites: Changing visits, evaluations and posts. Annals of Tourism Research, 57, 94-112.

30. Maswera, T., Dawson, R., \& Edwards, J. (2006). Assessing the levels of knowledge transfer within e-commerce websites of tourist organisations in Africa. Electronic Journal of Knowledge Management, 4(1), 59-66.

31. Hernandéz, B., Jiménez, J., \& Martín, M. J. (2009). Key website factors in e-Business strategy. International Journal of Information Management, 29, 362-371.

32. Atay, L., Morkoc, D. K., Gayler, J., \& Hall, J. (2011). The evaluation of the use of websites by four and five-star hotels in the Marmara region of Turkey. International Journal of Hospitality \& Tourism Systems, 4(2), 1-11.

33. Ting, P., Wang, S., Bau, D., \& Chiang, M. (2013). Website evaluation of the top 100 hotels using advanced content analysis and eMICA model. Cornell Hospitality Quarterly, 54, 284-293.

34. Doolin, B., Burgess, L., \& Cooper, J. (2002). Evaluating the use of the web for tourism marketing: A case study from New Zealand. Tourism Management, 23(5): 557-61. 